\title{
THE DIAGNOSTIC VALUE OF LEUKOCYTE STAINS IN LEUKAEMIAS
}

\author{
C. T. KeANE, B.Sc., M.B., B.Ch., B.A.O. \\ Dept. of Microbiology, Hospital for Sick Children, London, W.C.1.
}

\begin{abstract}
THE MORPHOLOGICAL characteristics of leukocytes are commonly defined with the aid of non-specific stains, usually one of the Romanowsky type such as the May-Grünwald-Giemsa or Leishman. Preparations made by such means are still the corner-stone of diagnostic haematology and their use is inextricably bound to the definition of the various cell types whether normal or pathological. Our present purpose will be to outline the deficiencies of these conventional techniques in the leukaemias and the extent to which they can be usefully supplemented by more specific staining methods.
\end{abstract}

\section{Historical}

While still a student in 1877 Ehrlich began investigations into the use of aniline dyes in staining microscopical preparations and so laid the foundations of the morphological study of the blood cells. Originally simple dyes were used in the clinical laboratory, and tissues were stained successively if a colour contrast was required. Most of the aniline dyes were in the form of salts of acids or bases and selective staining of different cell components was based on the fact that basic dyes were taken up by the acid nuclear component and acid dyes by the basic protoplasm. Ehrlich combined acid and basic dyes to form the so called "neutral" dyes and showed that in this way the staining principles of the original components were preserved and in addition new staining properties dependent upon the original component dyes could be developed. These were termed polychrome dyes. Jenner (1889) further simplified Ehrlich's technique. Instead of using two separate aqueous solutions which were mixed freshly each time, he collected the precipitate formed when eosin and methylene blue were mixed and redissolved in methyl alcohol and obtained a singie solution which was both fixative and stain. The next important step was made by Romanowsky (1890) who observed that by mixing old mould-covered solutions of methylene blue with eosin a stain was produced which brought out details which the Jenner or May-Grünwald stains failed to show. The basis of this difference was the formation of methylene azure, an oxidation product of methylene blue. Malachowski (1891) subsequently showed that this new metachromatic stain could be obtained consistently by alkalinisation of methylene blue with the subsequent addition of eosin, thus making it unnecessary to wait for mould formation to occur. There are now numerous modifications of the original Romanowsky method, including the methods of Wright (1902) Leishman (1901) and Reiter (1901).

Various descriptions of disease states which may now be regarded as examples of leukaemia can be found in the literature from the time of Hippocrates onward. The earliest microscopical observations were probably by Donne in 1893 . Leukaemia as a clinical entity was recognised as early as 1845 and independently described by Bennett and Virchow. Virchow appreciated that the cells involved were leukocytes and not primarily pus cells and proposed the name "weisses blut" (white blood). He further recognised a type in which lymphatic enlargement predominated in contradistinction to those cases in which splenomegaly was marked. A myelogenous form of leukaemia was described by Neumann (1870) but it was not until Ehrlich's blood staining methods came into use that the splenic and myelogenous forms were recognised as being identical.

Leukaemia with an acute course was first reported by Friedrich in 1857, and Ebstein in 1889 gave a clinical description of the outstanding symptoms of this form of the disease. At this time acute leukaemia was considered to be lymphatic in type and cases of chronic leukaemia in which the blood contained nongranular cells as well as granulocytes were spoken of as "mixed leukaemia". In 1900 Naegeli described the myeloblast and the identification of this cell as a member of the myeloid series, again as a result of progress in stain production, made it possible to recognize many cases of leukaemias, both acute and chronic, as myelogenous in type. Later Reschad and Schilling-Torgau (1913) described what they 
thought was a case of monocytic leukaemia, and their description suggested that there might be an additional form of leukaemia distinct from those recognised at that time. In subsequent years leukaemia without leukocytosis ("aleukaemic leukaemia") has been recognized.

\section{Classification of Leukaemia}

Leukaemia is conventionally divided into acute and chronic forms according to the time course of the disease and the morphological differences between the cell types principally found. In acute leukaemia the predominating cells are much more immature than in the chronic leukaemias. On this basis myelogenous (myeloid) and lymphogenous (lymphatic) forms are distinguished, however, there is dispute about the origin of the monocyte and this form of leukaemia is variously spoken of as myelogenous or histiocytic; for descriptive purposes this latter type will be referred to as monocytic. In chronic myelogenous leukaemia the neutrophil is usually the predominating cell whilst eosinophilic leukaemia and basophilic leukaemia are terms used for the varieties in which one of these cells predominates.

With the increasing importance accorded to the accurate recognition of white cell types, stress came to be laid on the necessity for unequivocal staining techniques. One special problem which has been the subject of recurrent difficulty is that of making as clear a distinction between the acute lymphatic and myeloid and leukaemias as can be done for the chronic forms.

\section{The Morphology of Blast Cells}

Since many cytochemical techniques have been specifically developed in relation to the problem of distinguishing the types of blast cells it is worth considering first the morphological features of these cells, and defining the manner in which cytochemical techniques may provide additional assistance. Their main features may be summarized as follows:

\section{Lymphoblasts}

These cells are characterised by a relatively large nucleus with a chromatin structure which is finer than that of the mature lymphocyte but more coarse than that seen in the myeloblast. There is a well defined fairly dense nuclear membrane, and usually one or two nucleoli are present, the outlines of which are sharp due to the presence of a nucleolar membrane. The cytoplasm stains a clear blue.

\section{Myeloblasts}

These cells are not normally found in the peripheral blood. They possess a relatively large nucleus round or oval in shape, and a small amount of cytoplasm. The nuclear membrane is inconspicuous with no condensation of chromatin close to the nuclear margin. The chromatin may appear in the form of very fine strands, giving the nucleus a sieve-like appearance, or the form of fine dust-like granules producing a uniform stippled effect. Several pale blue- to grey-staining nucleoli can usually be seen, having a less regular and clearly defined appearance than in the lymphoblast. The cytoplasm is blue and usually there is no clear zone around the nucleus. An important point of difference from the lymphoblast is the presence of granules which can be demonstrated with peroxidase stains in the more mature myeloblasts.

\section{Monoblasts}

These cells are usually larger (more than $14 \mu$ in diameter). Differentiation from the myeloblast may be very difficult. The cytoplasm is basophilic or greyish in colour. The nucleus is usually somewhat eccentric with fine stringy chromatin and one or two nucleoli.

Unfortunately in acute leukaemia the differ-o ences outlined become less apparent due to? morphological abnormalities which involve the nuclear and cytoplasmic architecture. Consequently there are many instances in which a clear recognition of the cell line cannot be made and these cells are variously described as "undifferentiated" or "unclassified". It is essentially in these instances that it might be hoped that specific cytochemical techniques would be of assistance in providing criteria for a more certain diagnosis.

\section{Specific Cytochemical Techniques}

Those most commonly used at the present time are listed in Table 1.

\section{(a) Nucleo-protein stains}

Cellular nucleoproteins are of two types depending upon whether the nucleic acid attached to the protein is deoxyribonucleic acid (DNA) or ribonucleic acid (RNA). RNA' is present in the nucleoli, DNA in the remainder of the nucleus.

(1) Feulgen Reaction: This reaction is specific for DNA and depends on the liberation of free nentose aldehyde groups from DNA after hydrolysis with warm hydrochloric acid. The liberated groups are combined with leukobasic fuscin to 
TABLE 1.

A. Cytochemical Stains Depending on NucleoPROTEIN CONTENT:

(1) Feulgen Reaction

(2) Methyl Green Pyronine

B. Cytoplasmic Stains in Common Use :-

(1) Peroxidase Reaction

(2) Sudan Black

(3) Periodic Acid Schiff (PAS)

(4) Alkaline Phosphatase

yield a magenta-coloured substance. A positive reaction is given by the nuclear chromatin and chromosomes and by the immediate products of their disintegration or dissolution, such as the Howell-Jolly body. The cytoplasm of all cell types is negative. The reaction is proportional to the DNA content of cells, thus staining intensity increases with maturity. Nucleoli of primitive cells do not react, but are often surrounded by a perinuclear zone of intensely staining chromatin.

(2) Methyl green pyronine reaction: This reaction is a more elegant way of studying nucleic acid distribution. Methyl green stains only DNA while pyronine is specific for RNA staining. Specificity can be confirmed by prior treatment of cells with purified nucleases when the staining reaction is predictably abolished.

\section{(b) Cytoplasmic stains in common use}

These are of considerable interest, but their practical value is not always apparent. They are based on a wide spectrum of cytochemical material. One methodological difficulty in attempting to describe the cytochemical reactions of individual types of blast cell is the presupposition that the identity of the blast cell is known without question. In other words the value of a cytochemical method has to be assessed by its reactions in cell types judged by morphological criteria, the difficulties of which have been already mentioned.

(1) Peroxidase Stains. Peroxidases contain a protein moiety and a prosthetic non-porphyrin complex. In the presence of hydrogen peroxide they catalyse the oxidation of many substrates. By providing a suitable substrate it is possible to use the reaction cytochemically.

$$
\begin{gathered}
\text { Peroxidase } \\
\mathrm{AH}_{2}+\mathrm{H}_{2} \mathrm{O}_{2}=\mathrm{A}+2 \mathrm{H}_{2} \mathrm{O}
\end{gathered}
$$

The substrate most commonly used is orthotoluidine (Quaglino and Flemans, 1958). The areas of reaction show a bright green colour increasing in intensity until with heavy overall positivity, coarse green-black granules are seen.
Primitive cells are usually scored as follows:

0 : negative reaction.

1: faint localized reaction.

2: strong reaction localized to cytoplasm.

3: heavy overall reaction partially obscuring the nucleus.

Late myeloblasts may show some staining, and positivity increases as maturity advances. Basophils are commonly negative. Monocytes may show a very weak granular reaction in a localized area. The other cells of the blood including lymphocytes, are peroxidase negative.

(2) Sudanophilia. Sudanophilic substances are cytoplasmic lipids which give a strong colour reaction with the dye Sudan black B. The method of Sheehan and Storey (1947) is widely used. There is still doubt about the exact nature of the sudanophilic substances present but it is most probable that they are lipo-protein complexes. Again a scoring system may be used based on the strength of the staining reaction. The more mature cells of the granular series give a strong staining reaction. Myeloblasts are usually negative or show a few granules close to the nucleus. Lymphocytes and lymphoblasts are always negative. Monocytes show a variable reaction. Some are negative while others show a week or strong granular reaction.

(3) Periodic Acid Schiff. Staining for glycogen by the MoManus reaction (McManus, 1946) is now widely used. Consecutive use of Romanowsky and PAS staining allows the basic morphology of the cell to be correlated with the glycogen content. The blue nucleus is in direct contrast to the intense red given by the glycogen. Myeloblasts are usually negative or show a diffuse cytoplasmic reaction. Positivity increases with maturity. The reaction in myelocytes and polymorphs is similar in both normal and leukaemic forms. Sometimes granules are scattered over the nucleus but these are few and do not obscure the nuclear detail. Lymphocytes contain less glycogen so many give a negative reaction although some $20 \%$ show moderately coarse discrete granules or blocks of positive staining material which are very variable in number. Monocytes also show staining. The reaction ranges from negative to coarsely positive most often with diffuse tinging and fine and coarse granules. Again a scoring system may be used.

\section{Alkaline Phosphatase}

This enzyme liberates phosphate from many alcoholic or phenolic phosphomonoesters at alkaline $\mathrm{pH}$. Two generally available techniques are used for its demonstration cytochemically. 
The first depends on the cellular enzyme acting on a suitable phosphomonoester in the presence of ions capable of forming an insoluble compound with released phosphate at the required $\mathrm{pH}$. Insoluble calcium phosphate is localized at the sites of enzyme activity when the preparation is incubated with a glycerophosphate at $\mathrm{pH} 9$ in the presence of calcium ions. This method can also be adapted for acid phosphatase. However the method more commonly used is a modification by Hayhoe and Quaglino (1958) of the method described by Kaplow (1955). Here the substrate is 2-naphthyl phosphate. Hydrolysis occurs and the liberated naphthyl is coupled with a diazotized amine to form an insoluble coloured precipitate.

The mature neutrophil contains alkaline phosphatase. Metamyelocytes sometimes give a faintly positive reaction, although other marrow cells including the younger granulocyte precursors fail to react. Reticulo-endothelial cells are exceptional and show strong enzyme activity. Polymorphs of bone marrow contain $50 \%$ less alkaline phosphatase than those in peripheral blood. Activity in these cells is indicated by a reddish brown precipitate. Cells are scored according to positivity on a 0 to 4 scale and 100 consecutive cell ratings added to give a total score for any blood sample, mature neutrophils from normal individua!s having scores from 14 to 100 .

The findings in various diseases are as follows: High scores are found in leukaemoid reactions, infectious leukocytosis, non-leukaemic myeloproliferative diseases, Hodgkin's disease and pregnancy. Low scores are found in chronic granulocytic leukaemia in relapse, in myeloblastic leukaemia and in paroxysmal nocturnal haemoglobinuria. By contrast, normal to high scores occur in lymphatic leukaemias and high scores in lymphoblastic leukaemia. Intermediate scores are found in monocytic leukaemia. Many of these non-leukaemic conditions present themselves in the differential diagnosis of leukaemia, and hence the potential importance of this test.

Many other enzymes are being investigated at present in leukocytes including esterases (Gomori, 1953; Moloney, Fliegelman and McPherson, 1959) phosphorylases (Takeuchi and Kinoshita, 1956; Hayhoe, Quaglino and Doll (1964) and dehydrogenases. Discrepancies, however, have been common with different technical methods. It is still too early to say if any of these enzymes have any diagnostic or therapeutic relevance.

\section{Discussion}

It cannot be said that the problem of the cytological diagnosis of leukaemia can be solved by the indiscriminate application of cytochemical tests. Morphological criteria still probably give the most useful information in determining the diagnosis and type of leukaemia. Additional information can sometimes be derived by the use of the techniques in Table 1 not merely in providing diagnostic information but also in refining the morphological details. For instance, nucleoli may not always be readily visible and their location can be more easily seen by using the Feulgen or methyl green pyronine reactions.

The first attempt to augment the information provided by the Romanowsky stains was by Schultze (1909) who introduced the oxidase stain, followed by Graham (1916) who introduced the peroxidase reaction but their diagnostic use was limited because although late myeloblasts may show staining, early myeloblasts and especially leukaemic myeloblasts usually give a negative reaction. It cannot therefore be assured that primitive cells giving a totally negative reaction are necessarily lyme phoblasts.

The deficiencies of the peroxidase reaction lect Storti and Perugini (1951) to study the sudano philia of primitive cells from 16 cases of acute leukaemia. Immature cells, apparently undifferentiated in smears stained by Romanowsky methods, showed sudanophilia resembling that of normal promyelocytes and myelocytes or that of normal monocytes. In a more recent series of 140 cases Hayhoe, Quaglino and Doll (1964) found that the Sudan black reaction was indeed useful in distinguishing the different forms of acute leukaemia. The main groups emerged; a negative (probably lymphoid) group, and a positive group of myeloid origin, the latter containing myeloblastic and mixed myelo-monoblastic varieties of cells.

The PAS reaction is not primarily helpful in separating different groups of acute leukaemia. Marked differences in quantity and distribution of staining material occur in different groups of patients and in cases within the same group In a 'typical' overall pattern, cases having sudanophilia in the blast cells similar to that of granulocytes and monocytes, frequently show some degree of diffuse PAS staining, while those with a negative sudan black reaction show almost invariably coarse granules and blocks in some at least of the primitive cells.

The alkaline phosphatase reaction would appear to be potentially useful in the differentia-

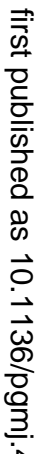


TABLE 2

SUMMARY OF CLASSICAL STAINING PATTERNS IN LEUKAEMIC WHITE CELLS USING THE COMMON CYTOCHEMICAL CYTOPLASMIC STAINS

\begin{tabular}{|c|c|c|c|c|c|c|c|c|c|c|c|}
\hline \multirow[t]{2}{*}{ Reaction } & \multirow[t]{2}{*}{$\begin{array}{c}\text { Lym- } \\
\text { phoblast }\end{array}$} & \multirow[t]{2}{*}{$\begin{array}{c}\text { Lym- } \\
\text { phocyte }\end{array}$} & \multirow[t]{2}{*}{$\begin{array}{c}\text { Myelo- } \\
\text { blast }\end{array}$} & \multirow[t]{2}{*}{$\begin{array}{l}\text { Myelo- } \\
\text { cyte }\end{array}$} & \multicolumn{5}{|c|}{ Neutrophils in the following } & \multirow[t]{2}{*}{$\begin{array}{c}\text { Mono- } \\
\text { blast }\end{array}$} & \multirow[t]{2}{*}{$\begin{array}{l}\text { Mono- } \\
\text { cyte }\end{array}$} \\
\hline & & & & & $\begin{array}{c}\text { Acute } \\
\text { Myelo- } \\
\text { genous } \\
\text { Leu- } \\
\text { kaemia }\end{array}$ & $\begin{array}{c}\text { Chronic } \\
\text { Myelo- } \\
\text { genous } \\
\text { Leu- } \\
\text { kaemia }\end{array}$ & $\begin{array}{c}\text { Acute } \\
\text { Lym- } \\
\text { phatic } \\
\text { Leu- } \\
\text { kaemia }\end{array}$ & $\begin{array}{c}\text { Chronic } \\
\text { Lym- } \\
\text { phatic } \\
\text { Leu- } \\
\text { kaemia }\end{array}$ & $\begin{array}{c}\text { Acute } \\
\text { Mono- } \\
\text { blastic } \\
\text { kaemia }\end{array}$ & & \\
\hline $\begin{array}{l}\text { Peroxi- } \\
\text { dase }\end{array}$ & O & O & + & ++ & ++++ & ++++ & ++++ & ++++ & ++++ & 0 & \pm \\
\hline P.A.S. & + & + & \pm & ++ & ++++ & ++++ & ++++ & ++++ & ++++ & \pm & + \\
\hline $\begin{array}{l}\text { Sudan } \\
\text { Black }\end{array}$ & O & O & + & ++ & ++++ & ++++ & +++ & ++++ & ++++ & O & O \\
\hline $\begin{array}{l}\text { Alkaline } \\
\text { Phos- } \\
\text { phatase }\end{array}$ & 0 & O & 0 & 0 & 0 & 0 & +++ & +++ & ++ & 0 & 0 \\
\hline
\end{tabular}

Cell raings on strength of staining reaction:-

tion of acute leukaemia, but great variation occurs in the neutrophil alkaline phosphatase level. Though the classical patterns are as described, frequently those cases in which the morphological findings are equivocal also show paradoxical staining for alkaline phosphatase and at times the cytochemical diagnosis is found to be at variance with the cytological findings.

One of the first cytochemical studies using a wide range of reactions in acute leukaemia was by Hertl (1959) who studied 25 cases and differentiated a multiplicity of cell types which he considered to represent variants from the myeloblastic and granulocytic cell series. He found little evidence of clearly separable monoblastic, lymphoblastic or other types of acute leukaemia. On the other hand Hayhoe and others (1964) studied preparations from 140 consecutive cases using the Jenner-Giemsa technique and the four common cytochemical techniques. They assessed their results statistically with the aid of a computer and by contrast with Hertl's view showed that the material could reasonably be interpreted as falling into four main groups, corresponding to lymphoblastic leukaemia, myeloblastic leukaemia, monocytic leukaemia and a minority group of unclassified cases.

Though at the present time the cytochemical tests reviewed yield limited assistance to the diagnosis of the type of acute leukaemia, the important fact is established that cells which may appear morphologically similar may give
$\mathrm{O}, \pm,+,++$

different chemical reactions. Distinction between the various types of acute leukaemia whenever possible are important since there may be differences in their therapeutic response (Whitby 1958). A further possibility also arises: should it be found that enzyme of defects are consistently present before the onset of leukaemia then their determination might be used to anticipate its onset in a prodromal phase. There remains the possibility that further investigation may reveal chemical spectra capable of characterising cell types more clearly than do morphological criteria alone.

\section{Summary}

The value of non-specific and cytochemical stains in the diagnosis of acute leukaemia has been discussed. Non-specific stains for studying leukocyte morphology remain at present the basis for the recognition of leukaemic states but already cytochemical stains are of some value in assessing the recognition of the particular blast cell type involved. Such stains are best used in combinations, since there is no such single staining method of unequivocal value in making such distinction.

At the present time the most satisfactory basis of separating the different types of leukaemia would appear to be on their morphological staining characteristics with the addition of the degree of sudanophilia (Table 2), while in the differentiation of leukaemoid and leukaemic states the neutrophil alkaline phosphatse has proved a considerable advance. 
I would like to thank Professor T. A. J. Prankerd and Dr. A. J. Bowdler who read through the script and gave many valuable suggestions.

\section{REFERENCES}

BenNeTt, J. H. (1845): Case of Hypertrophy of the Spleen and Liver in Which Death Took Place from Suppuration of the Blood, $M . \& S$. J., 64, 413.

DAMESheK, W., and Gunz, F. (1964): 'Leukaemia. New York and London: Grune \& Stratton.

DONNE (1893): Cited in, Leukaemia and Allied Disorders by C. E. Forkner. The Macmillan Company 1938 (bibliography).

EBSTEIN, W. (1889): Ueber die Acute Leukamie und Pseudoleukamie, Dtsch Arch. Klin. Med., 44, 343.

Feulgen, R., and Rossenbeck, H. (1924): Mikroskopisch-Chemischer Nachweis einer Nucleinsäure von Typus der Thyronucleinsäure und die darauf behrunde Elective Färburg Von Zellkernen in mikroskopischen Präparaten, Z. Phys. Chem., 135, 203.

FrIEDREICH, N. (1857): Ein neuer Fall, von Leukamie, Virchows Arch. path. Anat., 12, 37.

GoMORI G. (1951): Histochemical Staining Methods. In: Methods in Medical Research, Vol. 4. p. 14, ed. M. B. Vischer. Chicago: Year Book Publishers.

GrahaM, G. S. (1916): The Oxidizing Ferment of the Myelocyte Series of Cells and its Demonstration by an Alpha Naphtol-pyronin Method, J. med. Res., 35, 231.

Hayhoe, F. G. J., and Quaglino, D. (1958): Cytochemical Demonstration and Measurement of Leukocyte Alkaline Phosphatase Activity in Normal and Pathological States by a Modified Azo-dye Coupling Techniue, Brit. J. Haemat., 4, 375.

HayHOE, F. G. J., Quaglino, D., and Doll, R. (1964): The Cytology and Cytochemistry of Acute Leukaemias. A Study of 140 Cases, Spec. Rep. Ser. med. Res. Coun. (Lond.) p. 58, 54, 60.

HERTL, M. (1959): Morphologische and Zytochemische Untersuchungenam Zellen der Akuten Leukose, Folia Haemat. (Frankfurt), Neue. Folge, 3, 296.
Jolly, J. (1923): Traité Technique d'hematologic, $\frac{\widehat{D}}{\mathbb{Q}}$ 2 Vol. Paris: Maloine et Fils.

Kaplow, L. S. (1955): A Histochemical Procedure $\subsetneq$ for Localizing and Evaluating Leukocyte Alkaline Phosphatase Activity in Smears of Blood and Marrow, Blood, 10, 1023.

McManus, J. F. A. (1946): Histochemical Demonst- $\frac{\bar{\sigma}}{\bar{\sigma}}$ ration of Mucin after Periodic Acid, Nature (Lond.), 158, 202.

Moloney, W. C., Fliegelman, L., and McPherson, K. (1959): The Use of Napthol AS-D Chloroacetate as a Substrate for the Study of Leukocyte $\vec{P}$ Esterase Activity, J. Histochem. Cytochem., 7, 306.

NAEGELI, O. (1900): Ueber Nothes Knochenmark $\vec{\omega}$ und Myeloblasten, Dtsch med. Wschr., 26, 287.

NeumanN, E. (1870 and 1872): Ein Fall von Leuk-aemic mit Erkrankung des Knochenmarkes, Arch. 3 Heilk., 11, 1; 13, 502.

Quaglino, D., and Flemans, R. (1958): Peroxidase Staining in Leukocytes, Lancet, ii, 1020.

Reschad, H., and Schilling-ToRgau, V. (1913): ! Ueber eine Neue Leukaemic durch Fchte Ueberg- of angsformen (Splenozytenleukamie) und ihre Bedeu- $\omega$ tung fur die Seibstandigkeit diesen Zellen, Munch. 윽 med. Wschr., 60, 1981.

SCHULTZE, W. H. (1909): Die Oxydasereaktion au Gewebschnitten und ihre Bedeutung fur die Patho- $\mathbb{D}$ logic Zugleich ein Beitrag zur Differential-diagnose der Leukamien, Beitr. path. Anat., 45, 127.

SheehaN, H. L., and Storey, G. W. (1947): An Improved Method of Staining Leukocyte Granules with Sudan Black B., J. Path. Bact., 59, 336.

Storti, E., and Porugini, S. (1951): Cytochemicồ ज़ Researches on the Lipids of the Haematic CeEs with Particular Attention to Those of Acute Leukosis, Acta Haemat. (Basel), 5, 321.

TAKeUCHI, T., and KINOShITA, K. (1956): Histochemical Demonstration of Phosphorylase in Blood and Bone Marrow Cells, Blood, 11, 373.

Virchow, R. (1846): Weisses Blut und Milztumaren, Med. Ztg., 15, 157, 163, 1846. 